| Radiocarion, Vol. 7, 1965, P. 47-53]

\title{
GEOCHRON LABORATORIES, INC. RADIOCARBON MEASUREMENTS I
}

\author{
HAROLD W. KRUEGER and C. FRANCIS WEEKS \\ Geochron Laboratories, Inc., Cambridge, Massachusetts \\ INTRODUCTION
}

Geochron Laboratories, Inc. $C^{1 \cdot 4}$ facilities began operations in April 1963. Some of the results obtained during the past year have been released by our clients and are presented below.

Sample types and pretreatment: Rigorous pretreatment procedures are routinely applied and special procedures have been developed for unusual sample types. Pretreatment of combustible materials consists of hand removal of gross impurities, treatment with hot dilute $\mathrm{HCl}$ to remove carbonates or other soluble salts, treatment with hot $2 \mathrm{~N} \mathrm{Na(OH}$ to remove humic acids when necessary, and thorough rinsing. Shell and bone samples receive a physical cleaning followed by removal of surface material in acid. Bone and shell samples, after cleaning, are treated in a special apparatus which separates and recovers both the carbonate and collagen (or conchiolin) fractions in a manner similar to that of Berger, Horney and Libby (1964). Pretreatment procedures are modified as necessary to conform with the specific requirements of each sample.

Chemical conversion: Combustible samples are burned to completion in oxygen and the resulting $\mathrm{CO}_{2}$ is purified. The combustion system is completely cleaned and all reagents are replaced for each sample combustion. The $\mathrm{CO}_{2}$ of shells or carbonate materials is evolved with $\mathrm{H}_{3} \mathrm{PO}_{4}$ and purified.

The $\mathrm{CO}_{2}$ samples are converted to methane in a high-pressure reactor and the methane is purified in an apparatus similar to that of Fairhall, Schell and Takashima (1961). Specially selected tritium-free hydrogen is used in the catalytic conversion, and provision has been made for quantitative removal of radon. The yield of methane normally exceeds $98 \%$, and the gas is of high purity, as evidenced by its freezing characteristics and by its counting behavior.

Sample counting and counting equipment: Counting equipment consists of lead, borax solution, and mercury shielding; a multiple-anode annular guard counter; $2 \mathrm{~L}$ detector; and complete electronics. The detector has a background rate for methane at $1 \mathrm{~atm}$ of $5.9 \mathrm{cpm}$. Background rate is proportional to pressure (see Dorn et al., 1962) and is $6.6 \mathrm{cpm}$ at $2 \mathrm{~atm}$ of methane. Most sample counts are performed at 1 or 2 atm although counting characteristics are satisfactory at pressures as high as 5 atm.

Our modern standard is $95 \%$ of the rate of NBS oxalic acid and this rate is 11.6 net $\mathrm{cpm}$ at $1 \mathrm{~atm}$. Ages are calculated using the 5568 year half life and 1950 as reference year. Samples are counted for $1000 \mathrm{~min}$ or 10,000 counts, longer if needed or requested for added precision. Present precision at $2 \mathrm{~atm}$ yields maximum ages of about $39,000 \mathrm{yr}$ although older ages may be determined on large samples at higher counting pressures. 


\section{SAMPLE DESCRIPTIONS}

I. GEOLOGIC SAMPLES

\section{A. United States}

\section{GX-145. Missouri Dire Wolf I}

$13,170 \pm 600$

11,220 в.C.

Fragments of limbs and rib hones of Canis dirus, from Powder Mill cave, (Owls Bend, Shannon Co., Missouri ( $36^{\circ} 11^{\prime} \mathrm{N}$ Lat, $91^{\circ} 10^{\prime} \mathrm{W}$ Long). Skeleton was buried in sediments deposited by vadose water. Coll. 1964, described (Galbreath, 1964) and subm. hy E. C. Galbreath, Southern Illinois Univ., Carbondale, Illinois. Comment (E.C.G.) : date from carbonate fraction of bone roughly agrees with dates from dire wolves of pit 3 at Rancho la Brea, California.

\section{GX-194. Dune peat, Lane County, Oregon}

Sandy peat with fragments of coarse wood exposed in SE 1/4, NW 1/1. NW 1/4, Sec. 22, T 18 S, R 11 W, Lane Co., Oregon $\left(43^{\circ} 59^{\prime} \mathrm{N} \mathrm{Lat,} 124^{\circ} 7^{\prime} \mathrm{W}\right.$ Long). Crops out under dune sand along E side of Siuslaw River estuary at hase of wave-cut scarp. Coll. and sulm. 1964 hy E. R. Hampton. I. S. Geol. Survey, Portland, Oregon.

\section{B. Australia}

\section{GX-105. Boolcunda Creek Nototherium}

$14,000 \pm 225$

Bone fragments from jaw of Nototherium sp., found on S bank Boolcunda Creek, $1 \mathrm{mi} \mathrm{W}$ of Langwarren Homestead, E edge of Willochra plain, South Australia $\left(32^{\circ} 12^{\prime} \mathrm{S}\right.$ Lat, $138^{\circ} 17^{\prime} \mathrm{E}$ Long), $10 \mathrm{ft}$ below surface of dissected outwash fan, imbedded in red clay and gravel of Langwarren Formation. Coll. 1963 by C. R. Twidale and others; subm. by C. R. Twidale, Univ. of Adelaide, Adelaide, South Australia. Comment: date, obtained on carbonate fraction of hone after extensive treatment to remove surficial material, agrees with Twidale's estimated age.

\section{ARCHAEOLOGIC SAMPLES \\ A. Eastern United States}

\section{GX-193. Dalton zone charcoal, Alabama}

Charcoal fragments in sand from stratified Indian-shelter site near Asbury. Marshall Co., Alabama (34 $25^{\prime} \mathrm{N}$ Lat, $86^{\circ} 10^{\prime} \mathrm{W}$ Long $)$, from 53 in. depth. in lowest occupation zone of site (Dalton zone). Coll. 1963; subm. by D. L. DeJarnette, Univ. of Alabama Mus., Moundville, Alabama. Comment (D.L.DeJ.) : date is much too young for Dalton material. Charcoal is probably intrusive and not truly associated with Dalton material nearby. Sample was very small; diluted for counting.

\section{GX-155. Alligator Lake Site, Florida}

$2575 \pm 80$

625 B.C.

Charcoal from Alligator Lake site, Walton Co., Florida $\left(30^{\circ} 19^{\prime} \mathrm{N}\right.$ Lat. $86^{\circ} 10^{\prime} \mathrm{W}$ Long), in sand dunes ca. $300 \mathrm{yd}$ inland from Gulf of Mexico. From old land surface in pit 10, area A. in association with ceramics of Deptford 
culture. Coll. 1961 by W. C. Lazarus; subm. by W. C. Lazarus, Florida State Univ., Tallahassee, Florida. Comment (W.C.L.): date is compatible with reramic sequences and other artifacts.

\section{B. Western United States and Hawaii}

GX-107. Hearth charcoal, Craig, Missouri

$$
\begin{array}{r}
1270 \pm 100 \\
\text { A.D. } 680
\end{array}
$$

Charcoal from circular pit hearth near Craig, Holt Co., Missouri $\left(40^{\circ} 15^{\prime}\right.$ $\mathrm{N}$ Lat, $95^{\circ} 24^{\prime} \mathrm{W}$ Long). Site is near Crundel mastodon site and is in disturbed Peoria loess. Coll. 1963 by R. A. Marshall; subm. by T. R. Beveridge, Missouri Geol. Survey, Rolla, Missouri.

\section{GX-147. Rinehardt Buffalo Kill, Montana}

Buffalo bones from prehistoric kill $50 \mathrm{mi}$ NE of Coonrad, Montana $\left(48^{\circ}\right.$ $30^{\prime} \mathrm{N}$ Lat, $111^{\circ} 20^{\prime} \mathrm{W}$ Long), at $5 \mathrm{ft}$ depth. Coll. and subm. by Carle Leavitt. Coonrad, Montana. Comment: purified collagen from bones was used for dating. Date agrees with best estimates of the age of the deposits.

\section{GX-146. Folsom, New Mexico site \\ $2650 \pm 130$ \\ 700 в.c.}

Charcoal from Archaic site in SE 1/4. NE 1/1, Sec. 12, T 30 N, R 28 E. Inion Co., New Mexico, from open cobble hearth $1 \mathrm{ft}$ below surface, id. as Towanda phase, Late Archaic horizon. Coll. 1963 and subm. by Kenneth Honea, Mus. of New Mexico, Santa Fe. Comment (K.H.) : first $\mathrm{C}^{14}$ date for a Late Archaic horizon site in NE New Mexico.

\section{Hawaii Voleanos National Park series}

Charcoal samples from site on Kalapana road. Hawaii Volcanos Natl. Park, Hawaii ( $19^{\circ} 18^{\prime} \mathrm{N}$ Lat, $155^{\circ} 3^{\prime} \mathrm{W}$ Long). Coll. 1963 and subm. by E. J. Ladd, City of Refuge Nat. Hist. Park, Honauna, Kona, Hawaii.

\section{GX-138. Charcoal, Site 911, F-6}

Site 911,20 to $22 \mathrm{~cm}$ level in Sec. F-6.

\section{GX-137. Charcoal, Site 911, E-4}

$$
190 \pm 100
$$

Site 911,8 to $13 \mathrm{~cm}$ level from fireplace. Sec. E-4 (B17).

\section{Altar de Sacrificios series}

$$
\text { C. Guatemala }
$$

Charcoal, ashes, seeds and bone from several sites in Altar de Sacrificios area, Dept. of Peten, Guatemala (ca. $16^{\circ} \mathrm{N}$ Lat, ca. $91^{\circ} \mathrm{W}$ Long), from a variety of archaeological associations as described. Coll. 1962 by A. L. Smith; subm. by C. R. Willey, Peabody Mus., Harvard Univ., Cambridge, Massarhusetts.

\section{GX-162. Altar de Sacrificios-1}

$$
2195 \pm 164
$$

Charcoal ashes from refuse fill of Structure B-1II, Sub-structure F, associated with San Felix (Middle Preclassic) pottery. Comment (C.R.W.) : ac(eptable but slightly later than anticipated. 
GX-163. Altar de Sacrificios-2

Charred whole beans from hase of Shaft B in Structure B-III, associated with San Felix (Middle Preclassic) pottery. Comment (G.R.W.) : acceptable but somewhat older than anticipated.

GX-164. Altar de Sacrificios-3

$$
\begin{aligned}
& 2245 \pm 125 \\
& 295 \text { в.C. }
\end{aligned}
$$

Carbonaceous ashes and gravel from hearth in Level 12 of Structure B-III, associated with San Felix (Middle Preclassic) pottery. Comment (G.R.W.) : acceptable but slightly later than anticipated.

\section{GX-165. Altar de Sacrificios-4}

$$
2450 \pm 120
$$

500 в.c.

Charred seeds from refuse fill of Structure B-II, Sub-structure C, associated with San Felix and Plancha (Middle and Late Preclassic) pottery. Comment (G.R.W.) : round date of 500 B.c. is fully acceptable for a transitional San Felix-to-Plancha context.

\section{GX-166. Altar de Sacrificios-5}

$$
\begin{array}{r}
1690 \\
\text { A.D. } 260
\end{array}
$$

Charcoal from refuse arbitrary level, House Mount 33, associated with Ayn (Early Classic) pottery. Comment (G.R.W.) : acceptable with GoodmanThompson calendrical correlation dating of Early Classic period.

\section{GX-167. Altar de Sacrificios-6 \\ $2030 \pm 120$ \\ 80 B.C.}

Charcoal from Structure A-I, test pit stratigraphy, from refuse fill associated with Chixoy (Late Classic-Tepeu I equivalent) pottery. Comment (G.R.W.) : too early for apparent context. Dates of either A.D. 600 to 700 (Goodman-Thompson correlation) or A.D. 300 to 400 (Spinden correlation) would be expected.

GX-168. Altar de Sacrificios-7

$1845 \pm 110$

Charcoal from near Structure A-III associated with burial 4. Early Boca (Late Classic-Tepeu 3 equivalent) associations. Comment (G.R.W.) : much too early. Dates of either A.D. 800 to 900 (Goodman-Thompson correlation) or A.D. 500 to 600 (Spinden correlation) would be expected.

\section{GX-169. Altar de Sacrificios-8}

$1990 \pm 130$

Charcoal fragments from fill between two structural levels, Structure A-II. associated with Late Pasion (Late Classic-Tepeu 2 equivalent) pottery. Comment (G.R.W.) : much too early. Dates of either A.D. 700 to 800 (GoodmanThompson correlation) or A.D. 400 to 500 (Spinden correlation) would be expected.

\section{GX-170. Altar de Sacrificios-9}

$$
1275 \pm 115
$$$$
\text { A.D. } 675
$$

Charcoal fragments from Structure A-XIX, refuse from stratigraphic pit level associated with Late Pasion phase (Late Classic-Tepeu 2 equivalent) pottery. Comment (G.R.W.) : satisfactory. 
GX-171. Altar de Sacrificios-10

$1965 \pm 225$

15 в.c.

Charred beans from Structure B-II associated with San Felix phase refuse (Middle Preclassic). Comment (G.R.W.) : appears too late for estimates of Middle Preclassic dates.

\section{GX-172. Altar de Sacrificios-11}

$2695 \pm 185$

745 в.C.

Human bone, mainly vertebrae, from skeleton of Burial 135. Xe phase rearly part of Middle Preclassic). Comment: collagen of bones was separated and dated. Comment (G.R.W.) : date agrees with general dating estimates.

GX-208. Altar de Sacrificios-12

$2725 \pm 80$

775 B.C.

Charcoal fragments from structure A-I, test pit stratigraphy. Good association with Early Pasion phase (Late Classic-Tepeu 2 equivalent) floor. Comment (G.R.W.) : much too early. Dates of A.D. 700 to 800 (Goodman-Thompson ('orrelation) or A.D. 400 to 500 (Spinden correlation) would be expected.

\section{Ica series, Peru}

$$
\text { D. Peru }
$$

Series of charcoal samples from desert sites about lca, Peru, and representing cooking fires. Subm. by J. H. Rowe, Iniv. of Calif., Berkeley.

GX-185. Erizo, Ica-1

$$
3890 \pm 90
$$

1940 в.c.

Charcoal from desert site bordering Hacienda Collango, Ica Valley, Peru $114^{\circ} 26^{\prime} 45^{\prime \prime} \mathrm{S}$ Lat, $75^{\circ} 39^{\prime} 40^{\prime \prime} \mathrm{W}$ Long), depth of 5 to $30 \mathrm{~cm}$. Coll. $1963 \mathrm{by}$ J. H. Rowe and P. J. Lyon. Comment (J.H.R.) : acceptable for this site.

\section{GX-186. Erizo, Ica-2}

$3820 \pm 85$

1870 B.C.

Charcoal from desert site bordering Hacienda Collango, Ica Valley, Peru $114^{\circ} 26^{\prime} 45^{\prime \prime} \mathrm{S}$ Lat, $75^{\circ} 39^{\prime} 40^{\prime \prime} \mathrm{W}$ Long), depth of 5 to $30 \mathrm{~cm}$. Coll. $1963 \mathrm{by}$ J. H. Rowe and P. J. Lyon. Comment (J.H.R.) : acceptable for this site.

\section{GX-187. Mastodonte, Ica}

$3745 \pm 165$

1795 B.c.

Charcoal from desert site on edge of Pampa de Villacuri, W of Ica, Peru ( $13^{\circ} 15^{\prime} \mathrm{S}$ Lat. $76^{\circ} 1^{\prime} \mathrm{W}$ Long), from depth of 5 to $30 \mathrm{~cm}$. Coll. 1962 by J. H. Rowe and T. C. Patterson. Comment (J.H.R.) : date appears to be ca. $450 \mathrm{yr}$ too early. Sample contained abundant carbonates and, although boiled thoroughly in $\mathrm{HCl}$, it may be contaminated with older carbon.

\section{Acacus Massif series, Libya}

$$
\text { E. Africa }
$$

Series of charcoal samples from sites in Acacus Massif. SW Libya $\left(25^{\circ} \mathrm{N}\right.$ Lat, $11^{\circ} \mathrm{E}$ Long), in association with paintings and structures of pastoral and prepastoral phases of the Sahara described by Mori (1961). Coll. 1963 and subm. by Fabrizio Mori, Rome, Italy. 


\section{GX-87. Uan Muhaggiag VI RD}

Charcoal from deposit of Lan Muhuggiag, Wadi Teshuinat. From excavation of cut $I$, level $B_{3}$, covering a sandstone block upon which two paintings of cattle have been found. Comment (F.M.): this is a date "ante quem" for paintings of middle pastoral phase of Sahara.

\section{GX-88. Uan Telocat I RD}

$6754 \pm 290$

4804 в.c.

Charcoal from deposit of Uan Telocat, Wadi Imha. Deposit adhering to wall of rock shelter on which prepastoral paintings have been found. Comment (F.M.) : this is an "ante quem" date for paintings found on wall and probably represents prepastoral phase of Sahara.

\section{GX-89. Uan Tabu I RD}

$7045 \pm 175$

5095 в.c.

Charcoal from deposit of Uan Tabu, Wadi Teshuinat, from a trial excavation under wooden structure of hut of middle pastoral phase, level F. Comment (F.M.) : date is of primary importance in framework of absolute chronology of pastoral phase in Sahara.

\section{GX-109. Sebanzi Hill, Lochinvar, Zambia $\quad 750 \pm 135$}

Charcoal from Sebanzi Hill site, Lochinvar Ranch, $28 \mathrm{mi}$ NW of Monze, Zambia ( $15^{\circ} 55^{\prime} \mathrm{S}$ Lat, $27^{\circ} 10^{\prime} \mathrm{E}$ Long), from $54 \mathrm{in}$. depth in occupation deposit on the Hill, Trench III, sq. A, level 9. Pottery made by Iron Age occupants has connections with Kangila ware of Batoka Plateau to the E. Coll. 1963 by D. W. Phillipson; subm. by B. M. Fagan, Natl. Mus. of Zambia, Livingstone, Zambia. Comment (B.M.F.) : sample provides date for initial occupation of Sebanzi Hill, expected to he A.D. 1500 or earlier.

\section{F. Saudi Arabia}

\section{GX-94. Um Ad Damar slag}

$1200 \pm 125$

A.D. 750

Residual charcoal found in slag at $\mathrm{lm}$ Ad Damar, Saudi Arabia $\left(23^{\circ} 15^{\prime}\right.$ $\mathrm{N}$ Lat, $41^{\circ} \mathrm{E}$ Long). Charcoal represents the wood used in ancient smelting fires. Coll. 1962 by S. K. Herness; subm. by S. A. Kazim, Ministry of Petroleum and Mineral Resources, Jeddah, Saudi Arabia. Comment (S.A.K.) : date agrees with other samples taken independently by members of U. S. Geol. Survey.

\section{GX-95. Mahawiyah slag}

$1225 \pm 140$

A.D. 725

Residual charcoal found in slag at Mahawiyah, Saudi Arabia $\left(21^{\circ} 20^{\prime} \mathrm{N}\right.$ Lat, $41^{\circ} 15^{\prime} \mathrm{E}$ Long). Represents the wood used in ancient smelting fires. Coll. 1963 by C. W. Smith; subm. by S. A. Kazim. Comment (S.A.K.) : date agrees with others reported from nearby areas by U. S. Geol. Survey.

\section{Ingaladdi series}

\section{G. Australia}

Samples obtained from site at Ingaladdi Waterhole, Willeroo Station, No. Territory, Australia ( $15^{\circ} 11^{\prime}$ S Lat, $131^{\circ} 24^{\prime}$ E Long). Coll. 1963 and subm. by D. J. Mulvaney, Univ. of Melbourne, Victoria, Australia. 


\section{GX-103. Ingaladdi 1}

$1545 \pm 75$

Charcoal from 37 to $48 \mathrm{~cm}$ below surface in grey loose sand, similar to modern ground surface. Comment (D.J. M.) : dates a culture using various stone points which persisted in this area until this century.

\section{GX-104. Ingaladdi 2}

$6255 \pm 135$ 4305 в.с.

Charcoal from depth of 85 to $98 \mathrm{~cm}$ beneath surface in mass of granular stone fragments suggesting possible climatic differences from modern deposition. Comment (D.J.M.) : dates a most distinct flake and core culture, bearing no relation to that dated by GX-103.

GX-108. Wombah Midden site 1

$1860 \pm 180$ A.D. 90

Charcoal from midden deposit at Wombah, via Iluke, New South Wales, Australia $\left(29^{\circ} 22^{\prime} \mathrm{S}\right.$ Lat, $153^{\circ} 17^{\prime} \mathrm{E}$ Long). From level IIA. deepest occupation level of site, in association with a heavy layer of shell. Coll. 1963 and subm. hy Isabel McBryde, Univ. of New England, Armidale, New South Wales, Australia. Comment (I. McB) : unpub. date on adjoining portion of this level reported by Cakushuin Univ. is ca. $700 \mathrm{yr}$ older. It is possible that accumulation of this level took several centuries.

Date list:

REFIRRINCA

Univ. of Washington I Dorn et al., 1962

Berger, R., Horney, A. G., and Libby, W. F., 1964, Radiocarbon dating of bone and shell from their organic components: Science. v. 144, 1. 999-1001.

Dorn, T. F., Fairhall, A. W., Schell, W. R., and Takashima, Y., 1962, Radiocarbon dating at the University of Washington I: Radiocarbon, v. 4, p. 1-12.

Fairhall, A. W., Schell, W. R., and Takashima, Y., 1961, Apparatus for methane synthesis for radiocarbon dating: Rev. Sci. Instruments, v. 32, p. 323-325.

Galbreath, E. C.. 1964, A dire wolf skeleton and Powder Mill Creek cave, Missouri: Trans. III Arad. Sci., v. 57, p. 224-242.

Mori, Fabrizio, 1961, Aspetti di cronologia sahariana alla luce dei ritrovamenti della V Missione paletnologica nell'Acacus: Ric. Sci.. v. 31, p. 204-215. 